American Journal of Applied Sciences 9 (1): 1-6, 2012

ISSN 1546-9239

(C) 2012 Science Publications

\title{
Biosurfactan Production by Bacillus sp. Isolated from Petroleum Contaminated Soils of Sirri Island
}

\author{
${ }^{1}$ Ghayyomi Jazeh, M., ${ }^{2}$ F. Forghani and ${ }^{2}$ Deog-Hwan Oh \\ ${ }^{1}$ Department of Microbiology, Islamic Azad University, \\ Tonekabon Branch, Tonekabon, Iran \\ ${ }^{2}$ Department of Food Science and Biotechnology, \\ Institute of Bioscience and Biotechnology, \\ Kangwon National University, Chuncheon, \\ Kangwondo 200-701, South Korea
}

\begin{abstract}
Problem statement: Biosurfactants are active surface components produced by some bacteria and fungi. These molecules reduce surface and interfacial tension in aqueous solutions and hydrocarbon mixtures. The most important application of biosurfactants is in oil industry to enhance oil quality and facilitate oil extraction. The aim of this study was to isolate biosurfactant producing bacteria and optimize the conditions like temperature and $\mathrm{pH}$ for maximum biosurfactant production. Approach: Samples were collected from 8 selected points of oil contaminated soils in Sirri IslandIran. Primary screening tests including hemolytic activity, Drop collapse technique and Oil Spreading method were preformed and species with the best results were picked for complementary screening tests like emulsification activity, foaming and surface tension measurement. Results: Totally, 160 bacteria species were isolated. During primary and complementary screening tests, 59 species showed hemolytic activity, 46 had drop collapsing ability and 18 species showed positive results in emulsification, foaming and surface tension reduction. Finally, two Bacillus sp. were found to be able to reduce surface tension more than $30 \mathrm{mNm}^{-1}$. Conclusion: Two strains with a high amount of biosurfactant production and emulsification ability were resulted from the present study. According to the high potential of Bacillus sp. especially for Microbial Enhanced Oil Recovery (MEOR) and Bioremediation of oil contamination we can hope that further study of the isolates characteristics and looking for new local strains can play an important role in their application in oil industry.
\end{abstract}

Key words: Biosurfactant, oil contaminated soils, Bacillus sp., Microbial Enhanced Oil Recovery (MEOR), drop collapse, hemolytic activity, emulsification activity

\section{INTRODUCTION}

Biosurfactants are biological amphipathic compounds produced by various Bactria, fungi and molds (Noudeh et al., 2007; Dehghan-Noudeh et al., 2009). They are generally lipid compounds whose features are related to two ends present in the molecule, one end is hydrocarbon part which is less soluble in water (hydrophobic end). The hydrophobic part of the molecules is a long- chain of fatty-acids, hydroxyl fatty acid or $\alpha$-alcyl hydroxy-fatty acids. The other end is hydrophilic, more soluble in water and consists of carbohydrate, amino acid, cyclic peptide, phosphate and carboxylic acid or alcohol (Chayabutra et al., 2001; Volchenko et al., 2007; Chen et al., 2007; MataSandoval et al., 1999; Maier and Soberon-Chavez,
2000). Due to their advantages such as lower toxicity, high biodegradability, higher foaming, better environmental compatibility, the ability to act in high temperatures, low $\mathrm{pH}$ and different salinity levels and low production costs, biosurfactants are preferred to synthetic and chemical surfactants (Dehghan-Noudeh et al., 2009; Deleu and Paquot, 2004). These components have extended applications in petrochemical and oil industries, pharmacy, medical, cosmetics, food and pharmaceutical (Makkar and Cameotra, 2002; Van Ginkel, 1996; Babu et al., 1996). Thus among all Oil industry is the greatest market of these compounds (Dyke et al., 1993). One of the major problems facing the modern industrial development is the power resources. From the economical point of view; pumping power losses during the flow of transported liquids in

Corresponding Author: Ghayyomi Jazeh, M., Department of Microbiology, Islamic Azad University, Tonekabon Branch, Tonekabon, Iran Tel: +98-21-88474088 Fax: +98-21-88426844 
pipelines are one of the major problems facing many industrial applications (especially petroleum). The most famous drag reducing agents are: Polymers, fibers, soaps or surfactants (Haider et al., 2011). Biological treatment most commonly involves the breakdown of contamination into nontoxic forms using microbiological processes. Thus, bioremediation may be defined as the use of living organisms to remove environmental pollutants from soil, water and gases (Mukred et al., 2008). Biosurfactant producing microorganisms are able to be used in bioremediation and oil leak clearance in Soil and water environments (Head and Swannell, 1999; Mulligan, 2005; Urum et al., 2006). Microbial Enhanced Oil Recovery (MEOR) is one of the most recent and practical aspects of biosurfactants application. Industrial and semiindustrial production of biosurfactants would be possible by isolation of appropriate species and evaluation of physiological and metabolic features beside Substrate utilization of crude materials (Okerentugba and Ezerony, 2003; Fiechter, 1992; Finnerty, 1994; Lazar et al., 2007). The aim of this study was to isolate local biosurfactant producing bacteria and optimize the conditions like temperature and $\mathrm{pH}$ for maximum biosurfactant production.

\section{MATERIALS AND METHODS}

Sampling: Samples were collected from 8 different areas of oil contaminated soils, extracted oil reservoirs, oil pipeline leakages and oil sewage and sludge dumps in Sirri Island, Persian Gulf, Iran.

Cultivation media: Culture media were synthesized in the lab by Banat method (Rahman et al., 2002a; Rasooli et al., 2008) for microorganism enrichment and Robert method (Robert et al., 1989; DehghanNoudeh et al., 2009; De Lima et al., 2009) for biosurfactant production (Table 1 and 2).

Primary isolation: Samples were aseptically transferred to laboratory and enriched in shaker incubator (n-BioTek, Korea) at $200 \mathrm{rpm}$ for 21 days in $30^{\circ} \mathrm{C}$ (Rahman et al., 2002b; 2002c; Cunha et al., 2004; Bicca et al., 1999). After enrichment serial dilutions in saline normal solution were prepared, cultivated on mineral salts agar media and incubated (Memmert and Germany) in $30^{\circ} \mathrm{C}$ for $48 \mathrm{~h}$. After purification, morphology of colonies was studied. Pure colonies were inoculated into mineral salts media and incubated in $30^{\circ} \mathrm{C}$ in shaker incubator $(200 \mathrm{rpm})$ for $96 \mathrm{~h}$ (Rahman et al., 2003). The same culture was used for further study of biosurfactant producing strains. To obtain cell free media when necessary, cultures were centrifuged (Boeco and Germany) at (4000 rpm) for 30 min in $4^{\circ} \mathrm{C}$ and supernatant was collected to perform the tests.

\section{Primary tests for screening of biosurfactant producing bacteria: \\ Hemolytic activity analysis: Isolates were screened} on blood agar plates (Merck) containing 5\% (v/v) sheep blood and incubated at $37^{\circ} \mathrm{C}$ for $48 \mathrm{~h}$. Hemolytic activity was detected by presence of a clear zone around bacterial colonies (Plaza et al., 2006; Youssef et al., 2004).

Drop collapse method: In this test, according to Bodour and Miller-Maier method (Youssef et al., 2004), a modified oil collapse test was carried out using 96 well microtiter-plates containing $100 \mu \mathrm{L}$ mineral oil which was equilibrated for an hour at room temperature. About $10 \mu \mathrm{L}$ of the culture was added to the surface of the oil. After $1 \mathrm{~min}$, the shape of the drop on the surface of the oil was observed. The results were interpreted as $(+)$ to $(+++)$ corresponding partial to complete spreading on the oil surface. Those cultures that gave rounded drops were scored as negative (-) indicating the lack of biosurfactant production.

Table 1: Mineral salts medium for enrichment and biosurfactant production

\begin{tabular}{lll}
\hline & $\begin{array}{l}\text { Mineral salts } \\
\text { medium for } \\
\text { enrichment }\left(\mathrm{g} \mathrm{L}^{-1}\right)\end{array}$ & $\begin{array}{l}\text { Mineral salts medium } \\
\text { for biosurfactant } \\
\text { production }\left(\mathrm{g} \mathrm{L}^{-1}\right)\end{array}$ \\
\hline$\left(\mathrm{NH}_{4}\right)_{2} \mathrm{SO}_{4}$ & 2.00 & - \\
$\mathrm{KH}_{2} \mathrm{PO}_{4}$ & 2.40 & 0.50 \\
$\mathrm{~K}_{2} \mathrm{HPO}_{4}$ & 4.80 & 1.00 \\
$\mathrm{MgCl}_{2}$ & 0.08 & - \\
$\left(\mathrm{NH}_{4}\right) \mathrm{MO}_{7} \mathrm{O}_{24} \cdot 4 \mathrm{H}_{2} \mathrm{O}$ & 0.01 & - \\
$\mathrm{CaCl}_{2} \cdot 2 \mathrm{H}_{2} \mathrm{O}$ & 0.03 & - \\
$\left.\mathrm{Citric}^{-1}\right)$ & 0.40 & - \\
$\mathrm{NaNO}_{3}$ & - & 4.00 \\
$\mathrm{MgSO}_{4} \cdot 7 \mathrm{H}_{2} \mathrm{O}$ & - & 0.50 \\
$\mathrm{KCl}_{\mathrm{FeSO}} .7 \mathrm{H}_{2} \mathrm{O}$ & - & 0.10 \\
Yeast extract & - & 0.01 \\
Trace element & - & 0.01 \\
Carbon source & $2(\mathrm{~mL})$ & $0.05(\mathrm{~mL})$ \\
\hline
\end{tabular}

Table 2: Trace elements, mineral salts medium for enrichment and biosurfactant production

\begin{tabular}{lll}
\hline & $\begin{array}{l}\text { Mineral salts } \\
\text { medium for } \\
\text { enrichment }\left(\mathrm{g} \mathrm{L}^{-1}\right)\end{array}$ & $\begin{array}{l}\text { Mineral salts medium } \\
\text { for biosurfactant } \\
\text { production }\left(\mathrm{g} \mathrm{L}^{-1}\right)\end{array}$ \\
\hline $\mathrm{FeSO}_{4} .7 \mathrm{H}_{2} \mathrm{O}$ & 1.00 & - \\
$\mathrm{NaMoO}_{4}$ & 2.00 & 0.10 \\
$\mathrm{MnCl}_{2}$ & 1.00 & 1.75 \\
$\mathrm{ZnSO}_{4} \cdot 7 \mathrm{H}_{2} \mathrm{O}$ & 0.03 & 3.10 \\
$\mathrm{CuSO}_{4} \cdot 5 \mathrm{H}_{2} \mathrm{O}$ & 0.25 & 2.00 \\
$\mathrm{CoCl}_{2} \cdot 6 \mathrm{H}_{2} \mathrm{O}$ & 0.25 & - \\
$\mathrm{H}_{3} \mathrm{BO}_{3}$ & - & 1.50 \\
\hline
\end{tabular}


Oil spreading method: Oil spreading technique was carried out according to the method described previously by Youssef et al. (2004) and Plaza et al. (2006). Briefly, $50 \mathrm{~mL}$ of distilled water was added to the petri plate followed by addition of $100 \mu \mathrm{L}$ of crude oil to the surface of water. Then $10 \mu \mathrm{L}$ of cell free culture broth was dropped on the crude oil surface. The diameter of clear zone on the oil surface was measured and compared to $10 \mu \mathrm{L}$ of distilled water as negative control.

Complementary tests for screening biosurfactant producing bacteria: Prominent strains with the best positive test results were selected for complementary tests.

Surface tension measurements: This method is the most common and assured method to identify biosurfactant production. Since surface tension reduction is depended on environment temperature, surface tensions of all samples were determined in $24^{\circ} \mathrm{C}$. Surface tension reduction was measured using Tensiometer (Kruss GmbH Hamburg and Germany) and by submerging the platinum ring in the cell free culture broth and recording the force required to pull it through the air-liquid interface (Batista et al., 2006; Volchenko et al., 2007; Cha et al., 2008). The results were compared to distilled water and medium composition (as negative control) and 20 (as a positive control).

Emulsification activity $\left(\mathbf{E}_{\mathbf{2 4}}\right)$ : The emulsification activity was measured using the method described by Rahman et al. (2003) (Dehghan-Noude et al., 2005) and Desai and Banat (1997) (Chayabutra et al., 2001). About $5 \mathrm{~mL}$ of hydrocarbon (Crude oil) and $5 \mathrm{~mL}$ of cell free medium (supernatant) were inoculated to a test tube and homogenized by vortexing (Genius and Germany) at high speed for $2 \mathrm{~min}$. After $24 \mathrm{~h}$, the emulsification activity was calculated using following formula (Lai et al., 2009):

E24 $(\%)=$ total height of the emulsified layer/total height of the liquid layer

Foam formation activity: All isolates with positive results in primary screening tests were grown separately in $250 \mathrm{~mL}$ Erlenmeyer flasks, each containing $50 \mathrm{~mL}$ of nutrient broth (Merck at $\mathrm{pH}$ 7.2) medium. The flasks were incubated at $37^{\circ} \mathrm{C}$ on a shaker incubator (200 rpm) for $96 \mathrm{~h}$. Foam activity was detected as duration of foam stability, foam height and foam shape in the graduated cylinder (Chayabutra et al., 2001; DehghanNoudeh et al., 2003).

\section{RESULTS}

A total number of 160 strains were isolated in the present study including 110 Gram positive and 20 Gram negative Rods. Also 15 Gram positive and 15 Gram negative spherical bacteria were isolated. Among these, 59 strains had beta-hemolytic activity, 46 were able to collapse oil and 20 could spread oil. Finally, 18 isolates were selected for complementary techniques after performing primary differential tests. These isolates showed different amounts of surface tension decrease from $29-56 \mathrm{mN} \mathrm{m}^{-1}$ and emulsification activity $\left(\mathrm{E}_{24}\right)$ from 51.54-80.36\% (Table 3, Fig. 1). Also 11 strains had foam formation activity of 30-135 min (Table 4, Fig. 2). According to the results and data analysis, strains $\mathrm{S}_{7}, \mathrm{NO} 7$ and $\mathrm{S}_{5}$, NO6 showed the best biosurfactant production rate.

Biosurfactant Production Enhancement by $\mathrm{pH}$ and Temperature Optimization: Changing media $\mathrm{pH}$ from 6.5 to 8 with a 0.5 shift showed that the two final isolates produced maximum biosurfactant levels in $\mathrm{pH}$ $=7$ (Fig 3). Also the optimized temperature was determined (Fig 4) (Rasooli et al., 2008; Priya and Usharani, 2009).

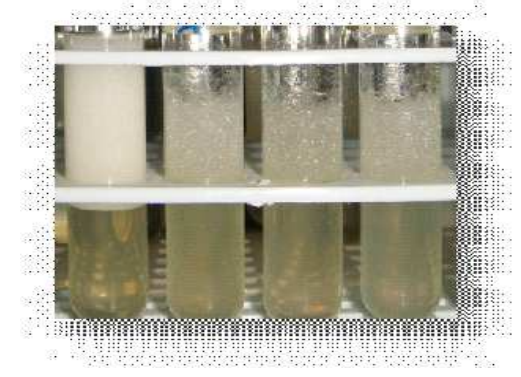

Fig. 1: Emulsification test for strain $\mathrm{S}_{5}$, No 6

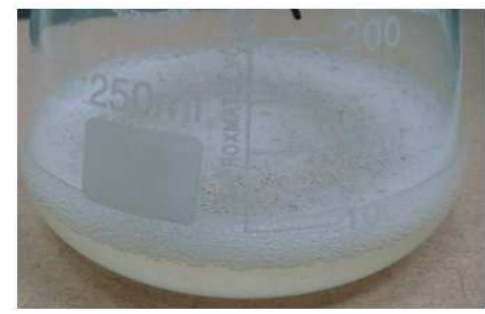

Fig. 2: Foam forming activity for strain $\mathrm{S}_{7}$, No7

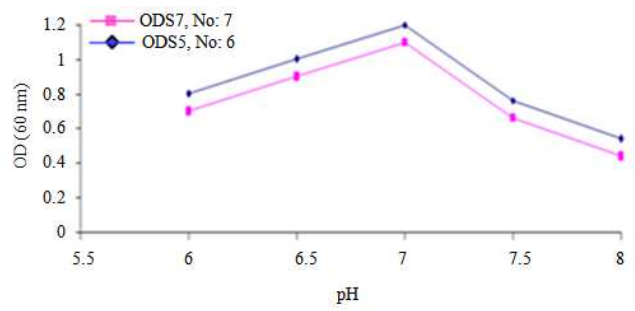

Fig. 3: Optimazation of $\mathrm{pH}$ 
Am. J. Applied Sci., 9 (1): 1-6, 2012

Table 3: Detection of biosurfactant producing isolates by preliminary and complementary screening methods

\begin{tabular}{|c|c|c|c|c|c|}
\hline Isolate & Hemolytic activity $^{*}$ & Oil spreading ${ }^{*}$ & Oil collapse $\mathrm{e}^{* *}$ & $\begin{array}{l}\text { Surface tension } \\
\left(\mathrm{mN} \mathrm{m}^{-1}\right) \pm \mathrm{SD}\end{array}$ & $\begin{array}{l}E_{24} \text { In presence } \\
\text { of crude oil }\end{array}$ \\
\hline$\overline{\mathrm{S}_{1}, \mathrm{NO} 3}$ & ++ & + & + & 42 & $69 / 12 \%$ \\
\hline $\mathrm{S}_{1}, \mathrm{NO} 4$ & ++ & ++ & + & 55 & $57 / 14 \%$ \\
\hline $\mathrm{S}_{2}, \mathrm{NO} 12$ & ++ & ++ & + & 46 & $59 / 96 \%$ \\
\hline $\mathrm{S}_{2}, \mathrm{NO} 5$ & + & + & + & 47 & $58 / 01 \%$ \\
\hline $\mathrm{S}_{2}, \mathrm{NO} 16$ & ++ & ++ & + & 55 & $55 / 16 \%$ \\
\hline $\mathrm{S}_{3}, \mathrm{NO19}$ & + & + & + & 50 & $61 / 12 \%$ \\
\hline $\mathrm{S}_{3}, \mathrm{NO} 13$ & - & + & ++ & 53 & $57 / 05 \%$ \\
\hline $\mathrm{S}_{3}, \mathrm{NO} 1$ & ++ & + & + & 49 & $65 / 08 \%$ \\
\hline $\mathrm{S}_{4}, \mathrm{NO} 8$ & ++ & - & ++ & 45 & $69 / 05 \%$ \\
\hline $\mathrm{S}_{4}, \mathrm{NO} 4$ & ++ & + & ++ & 49 & $71 / 26 \%$ \\
\hline $\mathrm{S}_{5}, \mathrm{NO6}$ & ++ & ++ & - & 40 & $79 / 98 \%$ \\
\hline $\mathrm{S}_{6}, \mathrm{NO} 3$ & + & ++ & ++ & 49 & $66 / 73 \%$ \\
\hline $\mathrm{S}_{6}, \mathrm{NO} 12$ & - & ++ & + & 51 & $80 / 06 \%$ \\
\hline $\mathrm{S}_{7}, \mathrm{NO} 7$ & +++ & + & ++ & 29 & $80 / 36 \%$ \\
\hline $\mathrm{S}_{7}, \mathrm{NO} 2$ & ++ & + & ++ & 45 & $51 / 54 \%$ \\
\hline $\mathrm{S}_{8}, \mathrm{NO} 14$ & + & - & ++ & 50 & $59 / 51 \%$ \\
\hline $\mathrm{S}_{8}, \mathrm{NO} 5$ & - & + & + & 56 & $72 / 85 \%$ \\
\hline $\mathrm{S}_{8}, \mathrm{NO} 12$ & + & + & + & 51 & $67 / 53 \%$ \\
\hline Water & - & - & - & 70 & - \\
\hline Culture medium & - & - & - & 65 & - \\
\hline Tween 20 & - & - & - & 35 & - \\
\hline
\end{tabular}

$(+)^{*}$ : For areas with less than $1 \mathrm{~cm}$ in diameter, $(++)^{*}$ : For areas with a diameter of 1 to $3 \mathrm{~cm},(+++)^{*}$ : For areas with more than $3 \mathrm{~cm}$ in diameter, $(+)^{* *}$ : Drops with diameters less than $1 / 5 \mathrm{~cm}, \quad(++)^{* *}$ : Drops with diameters between 1 and $1 / 5 \mathrm{~cm}, \quad(+++)^{* * *}$ : Drops with diameters more than $1 / 5 \mathrm{~cm}$

Table 4: Foam properties at different Strains

\begin{tabular}{lccc}
\hline \multicolumn{4}{c}{ Foam stability } \\
Isolate & course $(\mathrm{min})$ & Foam height $(\mathrm{mM})$ & Foam properties \\
\hline $\mathrm{S}_{1}, \mathrm{NO} 4(\mathrm{~A})$ & 95 & 53 & ++ \\
$\mathrm{S}_{2}, \mathrm{NO12}$ & 55 & 8 & + \\
$\mathrm{S}_{2}, \mathrm{NO5}$ & 45 & 8 & + \\
$\mathrm{S}_{3}, \mathrm{NO1}$ & 75 & 7 & + \\
$\mathrm{S}_{4}, \mathrm{NO8}$ & 75 & 11 & ++ \\
$\mathrm{S}_{4}, \mathrm{NO} 4$ & 35 & 7 & + \\
$\mathrm{S}_{5}, \mathrm{NO6}$ & 105 & 16 & ++ \\
$\mathrm{S}_{6}, \mathrm{NO3}$ & 30 & 7 & + \\
$\mathrm{S}_{7}, \mathrm{NO} 7$ & 135 & 28 & +++ \\
$\mathrm{S}_{7}, \mathrm{NO} 2$ & 60 & 9 & + \\
\hline
\end{tabular}

$(+)$ : Bubbles with coarse sizes, very disperse and low stability, $(++)$ : Bubbles with medium sizes, concentrated and medium stability, $(+++)$ : Bubbles with fine sizes, concentrated and high stability

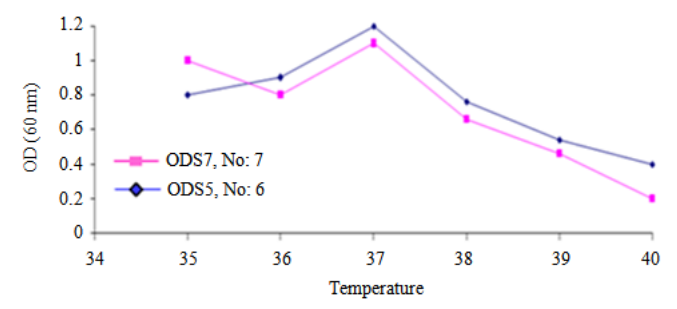

Fig. 4: Optimazation of temperature

\section{DISCUSSION}

As expected, isolated strains from oil contaminated soils of Sirri Island had a great ability in biosurfactant production. This was in accordance with the result of Firorenaz and colleagues work in (1991) that showed a doubled number of biosurfactant producing bacteria in oil contaminated soils (Francy et al., 1991). According to Banat (1995) study, an effective biosurfactant is the one that reduces water surface tension from $72-27 \mathrm{mN}$ $\mathrm{m}^{-1}$. Our two final isolates showed this ability in accordance with (Okerentugba and Eneronye (2003) (Benincasa et al., 2004) studies which both proved that strains isolated from areas with permanent contamination had better emulsification activity (Okerentugba and Ezerony, 2003; Francy et al., 1991).

\section{CONCLUSION}

MEOR represents a truly eco-friendly petroleum recovery process employing biotechnological resources and techniques that can be used to replace and augment the traditional EOR processes and flooding chemicals. Many countries have nvisaged that one-third of their oil recovery programs will utilize MEOR techniques by the year 2010 (Sen, 2008; Schneider and Tabeling, 2011). Surface active compounds or biosurfactants production has become more important in recent years. These compounds play an important role in increasing oil recovery (Banat, 1995; Sen, 2008). Isolation of two strains with high emulsification activity and biosurfactant production that have the potential to be industrially used both for MEOR and oil contamination bioremediation, proves that it is necessary to perform such researches in future to obtain novel results and localize bioscience application in oil industry of oil producing countries like Iran. 
Am. J. Applied Sci., 9 (1): 1-6, 2012

\section{REFERENCES}

Babu, P.S., A.N. Vaidya, A.S. Bai, R. Kapur and A. Juwarkar et al., 1996. Kinetics of biosurfactant production by Pseudomonas aeruginosa strain BS2 from industrial wastes. Biotechol. Lett., 18: 263268. DOI: $10.1007 / \mathrm{BF} 00142942$

Banat, I.M., 1995. Biosurfactants production and possible uses in microbial enhanced oil recovery and oil pollution remediation: A review. Bioresource Technol., 51: 1-12. DOI: 10.1016/0960-8524(94)00101-6

Batista, S.B., A.H. Mounteer, F.R. Amorim and M.R. Totola, 2006. Isolation and characterization of biosurfactant/bioemulsifier-producing bacteria from petroleum contaminated sites. Bioresour. Technol., 97: 868-875. DOI: 10.1016/j.biortech.2005.04.020

Benincasa, M., A. Abalos, I. Oliveira and A. Manresa, 2004. Chemical structure, surface properties and biological activities of the biosurfactant produced by Pseudomonas aeruginosa LBI from soapstock. Antonie Van Leeuwenhoek, 85: 1-8. PMID: 15028876

Bicca, F.C., L.C. Fleck and M.A.Z. Ayub, 1999. Production of biosurfactant by hydrocarbon degrading Rhodococcus ruber and Rhodococcus erythropolis. Rev. Microbiol., 30: 231-236. DOI: 10.1590/S0001-37141999000300008

Cha, M., N. Lee, M. Kim, M. Kim and S. Lee, 2008. Heterologous production of Pseudomonas aeruginosa EMS1 biosurfactant in Pseudomonas putida. Bioresour Technol., 99: 2192-2199. PMID: 17611103

Chayabutra, C., J. Wu and L.K. Ju, 2001. Rhamnolipid production by Pseudomonas aeruginosa under denitrification: Effects of limiting nutrients and carbon substrates. Biotechnol. Bioeng., 72: 25-33. PMID: 11084590

Chen, S.Y., Y.H Wei and J.S Chnd, 2007. Repeated $\mathrm{pH}$-stat fed-batch fermentation for rhamnolipid production with indigenous Pseudomonas aeruginosa S2. Applied Microbial. Biotechnol., 76: 67-74. DOI: 10.1007/s00253-007-0980-2

Cunha, C.D., M.D. Rosario, A.S. Rosado and S.G.F. Leite, 2004. Serratia sp. SVGG16: A promising biosurfactant producer isolated from tropical soil during growth with ethanol-blended gasoline. Process Biochem., 39: 2277-2282. DOI: 10.1016/j.procbio.2003.11.027

Lima, C.J.B.D., E.J. Ribeiro, E.F.C. Servulo, M.M. Resende and V.L. Cardoso, 2009. Biosurfactant production by Pseudomonas aeruginosa grown in residual soybean oil. Applied Biochem. Biotechnol., 52: 156-168. DOI: 10.1007/s12010-008-8188-1
Dehghan-Noude, G., M. Housaindokht and B.S. Bazzaz, 2005. Isolation, characterization and investigation of surface and hemolytic activities of a lipopeptide biosurfactant produced by Bacillus subtilis ATCC 6633. J. Microbiol., 43: 272-276. PMID: 15995646

Dehghan-Noudeh, G., B.S. Fazly Bazaz and M.R. Housaindokht, 2003. Comparative study of the hemolytic and Surface activities of the biosurfactant produced by Bacillus subtilis ATCC6633 With some synthetic surfactants. IJBMS., 6: 1-8.

Dehghan-Noudeh, G., M.H. Moshafi, E. Behravan, S. Torkzadeh and M.A. Afzadi, 2009. Screening three strains of Pseudomonas aeruginosa: Prediction of biosurfactant-producer strain. Am. J. Applied Sci., 6: 1453-1457. DOI: 10.3844/ajassp.2009.1453.1457

Deleu, M. and M. Paquot, 2004. From renewable vegetables resources to microorganisms: New trends in surfactants. Comptes Rendus Chimie, 7: 641-646. DOI: 10.1016/j.crci.2004.04.002

Desai, J.D. and I.M. Banat, 1997. Microbial production of surfactants and their commercial potential. Microbiol. Mol. Biol. Rev., 61: 47-64. PMID: 9106364

Dyke, M.I.V., S.L. Gulley, H. Lee and J.T. Trevors, 1993. Evaluation of microbial surfactants for recovery of hydrophobic pollutants from soil. J. Indus. Microbol. Biotechnol., 11: 163-170. DOI: 10.1007/BF01583718

Fiechter, A., 1992. Biosurfactants: Moving towards industrial application. Trend Biotechnol., 10: 208217. DOI: 10.1016/0167-7799(92)90215-H

Finnerty, W.R., 1994. Biosurfactants in environmental biotechnology. Curr. Opin. Biotechnol., 5: 291295. DOI: 10.1016/0958-1669(94)90031-0

Francy, D.S., J.M. Thomas, R.L. Raymond and C.H. Ward, 1991. Emulsification of hydrocarbons by subsurface bacteria. J. Indust. Microb. Biotechnol., 8: 237-246. DOI: 10.1007/BF01576061

Head, I.M. and R.P.J. Swannell, 1999. Bioremediation of petroleum hydrocarbon contaminants in marine habitats. Curr. Opin. Biotechnol., 10: 234-239. DOI: 10.1016/S0958-1669(99)80041-X

Lai, C.C., Y.C. Huang, Y.H. Wei and J.S. Chang, 2009. Biosurfactant-enhanced removal of total petroleum hydrocarbons from contaminated soil. J Hazard Mater., 167: 609-614. DOI: 10.1016/j.jhazmat.2009.01.017

Lazar, I., I.G. Petrisor and T.F. Yen, 2007. Microbial Enhanced Oil Recovery (MEOR). Petroleum Sci. Technol., 25: 1353-1366. DOI: $10.1080 / 10916460701287714$ 
Maier, R.M. and G. Soberon-Chavez, 2000. Pseudomonas aeruginosa rhamnolipids: Biosynthesis and potential applications. Applied Microbiol. Biotechnol., 54: 625-633. DOI: $10.1007 / \mathrm{s} 002530000443$

Makkar, R.S. and S.S. Cameotra, 2002. An update on the use of unconventional substrates for biosurfactant production and their new applications. Applied Microbiol. Biotechnol., 58: 428-434. PMID: 11954787

Mata-Sandoval, J.C., J. Karns and A. Torrents., 1999. High-performance liquid chromatography method for the characterization of rhamnolipid mixtures produced by pseudomonas aeruginosa UG2 on corn oil. J. Chromatogr. A., 864: 211-220. PMID: 10669288

Mukred, A.M., A.A. Hamid, A. Hamzah and W.M.W. Yusoff, 2008. Development of three bacteria consortium for the bioremediation of crude petroleum-oil in contaminated water. OnLine J. Biol. Sci., 8: 73-79. DOI: 10.3844/ojbsci.2008.73.79

Mulligan, C.N., 2005. Environmental applications for biosurfactants. Environ. Pollut., 133: 183-198. PMID: 15519450

Noudeh, G.D., M.H. Moshafi, P. Khazaeli and F. Akef, 2007. Studies on Bioemulsifier Production by Bacillus licheniformis PTCC 1595. Am. J. Pharmacol. Toxicol., 2: 164-169. DOI: 10.3844/ajptsp.2007.164.169

Okerentugba, P.O. and O.U. Ezerony, 2003. Petroleum degrading potentials of single and mixed microbial cultures isolated from rivers and refinery effluent in Nigeria. Afr. J. Biotechnol., 2: 288-292.

Plaza, G.A., I. Zjawiony and I.M. Banat, 2006. Use of different methods for detection of thermophilic biosurfactant-producing bacteria from hydrocarbon-contaminated and bioremediated soils. J. Petrol. Sci. Eng., 50: 71-77. DOI: 10.1016/j.petrol.2005.10.005

Priya, T. and G. Usharani, 2009. Comparative Study for Biosurfactant Production by Using Bacillus subtilis and Pseudomonas aeruginosa. Botany Res. Int., 2: 284-287.

Rahman, $\quad$ K.S., T. Rahman, P. Lakshmanaperummalsamy and I.M. Banat, 2002a. Occurrence of crude oil degrading bacteria in gasoline and diesel station soils. J. Basic Microbial., 42: 284-291. PMID: 12210553

Rahman, K.S.M., T.J. Rahman, S. McClean, R. Marchant and I.M. Banat, 2002b. Rhamnolipid biosurfactant production by strains of pseudomonas aeruginosa using low-cost raw materials. Biotechnol. Prog., 18: 1277-1281. DOI: $10.1021 / \mathrm{bp} 020071 \mathrm{x}$
Rahman, K.S.M., J. Thahira-Rahman, P. Lakshmanaperumalsamy and I.M. Banat, 2002c. Towards efficient crude oil degradation by a mixed bacterial consortium. Bioresource Technol., 85: 257-261. DOI: 10.1016/S0960-8524(02)00119-0

Rahman, K.S.M., T.J. Rahman, P. Lakshmanaperumalsamy, R. Marchant and I.M. Banat, 2003. The potential of bacterial isolates for emulsification with a range of hydrocarbons. Acta Biotechnol., 23: 335-345. DOI: 10.1002/abio.200390043

Rasooli, I., S.D.A. Astaneh, H. Borna and K.A. Barchini, 2008. A thermostable $\alpha$-amylase producing natural variant of Bacillus spp. isolated from soil in Iran. Am. J. Agric. Biol. Sci., 3: 591596. DOI: 10.3844/ajabssp.2008.591.596

Robert, M., M.E. Mercade, M.P. Bosch, J.L. Parra and M.J. Espuny et al., 1989. Effect of the carbon source on biosurfactant production by psuedomonas aeruginosa 44T1. Biotech. Lett. 11: 871-874. DOI: 10.1007/BF01026843

Schneider, M.H. and P. Tabeling, 2011. Lab-on-chip methodology in the energy industry: Wettability patterns and their impact on fluid displacement in oil reservoir models. Am. J. Applied Sci., 8: 927932. DOI: 10.3844/ajassp.2011.927.932

Sen, R., 2008. Biotechnology in petroleum recovery: The microbial EOR. Progress Energy Combustion Sci., 34: 714-724. DOI: 10.1016/j.pecs.2008.05.001

Urum, K., S. Grigson, T. Pekdemir and S. McMenamy, 2006. A comparison of the efficiency of different surfactants for removal of crude oil from contaminated soils. Chemosphere., 62: 1403-1410. DOI: 10.1016/j.chemosphere.2005.05.016

Ginkel, C.G., 1996. Complete degradation of xenobiotic surfactants by consortia of aerobic microorganism. Biodegradation, 7: 151-164. DOI: 10.1007/BF00114627

Volchenko, N.N., S.G. Karasev, D.V. Nimchenko and E.V. Karaseva, 2007. Cell hydrophobicity as a criterion of selection of bacterial producers of biosurfactants. Microbiology, 76: 112-114. DOI: 10.1134/S0026261707010158

Youssef, N.H., K.E. Duncan, D.P. Nagle, K.N. Savage and R.M. Knapp et al., 2004. Comparison of methods to detect biosurfactant production by diverse microorganisms. J. Microbiol. Methods, 56: 339-347. DOI: 10.1016/j.mimet.2003.11.001

Haider, L., M.T. Fischer, J.M. Frischer, J. Bauer and R. Hoftberger et al., 2011. Oxidative damage in multiple sclerosis lesions. Brain 134: 1914-1924. DOI: 10.1093/brain/awr128 